DOI:

http://e-journal.stit-islamic-village.ac.id/index.php/JECIES

\title{
PENGARUH VIDEO YOUTUBE "NUSSA" TERHADAP EGOCENTRIC SPEECH \\ (Penelitian Eksperimen Pada Anak Usia 4-5 Tahun di Ruang Publik Terpadu Ramah Anak Bahari Jakarta Selatan)
}

\author{
Andi Musda Mappapoleonro, Zahrati Mansoer, Ahmad Syaikhu, Dea Tasya \\ Sari, Herinto Sidik Iriansyah \\ STKIP Kusuma Negara \\ Email: \\ andimusda@stkipkusumanegara.ac.id, zahrati_mansoer@stkipkusumanegara.ac.id, \\ ahmadsyaikhu@stkipkusumanegara.ac.id, herinto@stkipkusumanegara.ac.id
}

Received: 20 Maret, 2020.

Accepted: 27 Maret, 2020.

Published: 30 Maret, 2020

\begin{abstract}
ABSTRAK
Penelitian ini bertujuan agar dapat membuktikan pengaruh penggunaan YouTube terhadap kemampuan berbicara egosentris anak (egocentric speech). Penelitian ini dilaksanakan selama satu bulan tepatnya yaitu bulan Juli-Agustus 2019, dengan jumlah sampel sebanyak 12 orang anak, pemilihan sampel peneltian dilakukan secara incidental sampling. Berdasarkan perhitungan diperoleh data bahwa diperoleh data kelompok anak yang sebelum diberi perlakuan pemutaran video YouTube dengan perolehan skor tertingi 30; skor terendah 20; rata-rata (mean) 24; nilai median $\left(M_{e}\right)$ 22,5; nilai modus $\left(M_{0}\right)$ 22, dan simpangan baku 3,89. Selanjutnya diperoleh data kelompok anak setelab diberi perlakuan video YouTube Nussa dengan perolehan skor tertingi 40; skor terendah 32; rata-rata (mean) 37,08; median $\left.M_{e}\right)$ 39,5; nilai modus $\left(M_{0}\right)$ 36,5; dan simpangan baku 2,539. Hal ini berdasarkan perbitungan bahwa diperoleb nilai thitung $(8,58)>$ $t_{\text {tabel }}(1,81)$ pada taraf signifikansi $a=0,05$, maka $H_{1}$ diterima dan $H_{0}$ ditolak. Kesimpulan peneliltian ini menunjukkan bahwa terdapat perbedaan yang signifikan pengaruh video YouTube Nussa terhadap kemampuan berbicara egosentris anak di Ruang Publik Terpadu Ramah Anak Bahari Jakarta Selatan.
\end{abstract}

Kata Kunci: Egocentric Speech, Video YouTube Nussa.

\section{PENDAHULUAN}

Indonesia merupakan sebuah negara kepulauan dengan jumlah populasi sekitar 255 juta penduduk, terpadat nomor empat di dunia. Jumlah tersebut tentunya mempengaruhi data penggunaan Internet di setiap tahunnya. Menurut lembaga riset pasar e-Marketer, populasi netter Tanah Air mencapai 83,7 juta orang pada tahun 2014 (Wicak : 2014). Setelah itu, data pengguna internet di Tanah Air melonjak naik pada tahun 2015 hingga 2016. 
Asosiasi Penyelenggara Jasa Internet Indonesia (APJII) merilis Survei Penetrasi dan Perilaku Pengguna Internet Indonesia Tahun 2017. Survei dilakukan terhadap 2.500 responden dari seluruh wilayah di Tanah Air. Dalam survei tersebut, APJII memaparkan jenis-jenis penggunaan internet oleh masyarakat Indonesia. Data APJII menemukan, hampir 90 persen layanan yang diakses oleh pengguna internet adalah untuk layanan perbincangan alias chatting. Setelah itu disusul oleh akses terhadap media sosial. Sebanyak 89,35 persen layanan yang diakses adalah chatting (Setiawan : 2018). Setelah itu, 87,13 persen untuk media sosial, upload (unggah) foto di Instagram, Facebook, YouTube dan sebagainya.

YouTube sebagai salah satu media sosial yang sering digunakan masyarakat Indonesia khususnya anak usia dini untuk menikmati video baik ataupun membuat video dan menguploadnya untuk mencapat tujuan yang diinginkannya dalam segi pendidikan maupun hiburan semata.. Youtube juga mempunyai aspek yang menguntungkan maupun merugikan bagi kehidupan manusia khususnya anak usia dini. Apabila kita amati, Youtube bukan lagi media social yang dinikmati oleh orang tua dan orang dewasa saja akan tetapi YouTube tersebut sudah dinikmati di kalangan anak usia dini. Tidak jarang dijumpai anak usia dini sudah lihai membawa handphone dan membuka YouTube. Pada saat anak rewel, orang tua dengan mudahnya memberikan handphone dan membuka YouTube agar anak diam dan orang tua dapat melanjutkan pekerjaan rumahnya atau pada saat anaknya sedang asyik membuka video dari YouTube, lalu orang tua mengambil handphone anaknya menjadi menangis sekencangkencangnya. Dan terkadang anak juga membuka YouTube dari bermenit-menit hingga berjam-jam lamanya. Bahkan anak-anak lebih asyik dengan membuka YouTube daripada mendengarkan perkataan orang tua atau orang lain.

Dapat disimpulkan bahwa anak sangat akrab dengan video YouTube. Hasil riset tersebut menghasilkan angka yang cukup besar. Dengan demikian, berarti jelas bahwa anak sudah terbiasa mengakses video di YouTube. Tanpa dan atau pengawasan orang tua pun, anak bisa mengakses sebuah aplikasi YouTube. Dalam menggunakan metode eksperimen melalui video YouTube, menjadikan anak lebih tertarik dalam mendapatkan materi yang diajarkan baik dirumah maupun disekolahnya. Egocentric speech anak dapat dikembangkan melalui metode eksperimen disekolah dengan menonton video YouTube.

Berdasarkan hal tersebut menjadikannya latar belakang penelitian ini, untuk mengetahui "Pengaruh video YouTube "NUSSA" terhadap egosentric speech anak usia 45 tahun". 


\section{METODE PENELITIAN}

Penelitian ini bertujuan untuk menemukan data yang akurat secara ilmiah tentang pengaruh video YouTube Nussa terhadap egocentric speech anak usia 4-5 tahun. Secara operasional penelitian ini bertujuan untuk mengetahui dan memperoleh data empiris tentang pengaruh video YouTube Nussa sebagai variabel bebas $(\mathrm{X})$ dan egocentric speech sebagai variabel terikat $(\mathrm{Y})$ anak usia 4-5 tahun di Ruang Publik Terpadu Ramah Anak Bahari Jakarta Selatan.

Penelitian ini dilaksanakan di Ruang Publik Terpadu Ramah Anak Bahari, Jalan Bahari RT 09/07 Kelurahan Gandaria Selatan, Kecamatan Cilandak, Kota Administrasi Jakarta Selatan. Waktu yang digunakan untuk melaksanakan penelitian ini adalah pada bulan Juli-Agustus tahun 2019.

Desain penelitian yang digunakan yaitu pre-experimental design dengan jenis the one-group pretest-post test design. Jenis ini diberikan pada satu kelompok yang diberi pre-test, diberi treatment, dan diberi post-test $\left(\mathrm{O}_{1}-\mathrm{X}-\mathrm{O}_{2}\right)$. Keberhasilan treatment (Arikunto, 2002) ditentukan dengan membandingkan nilai pre-test dan nilai post-test.

Adapun desain penelitian dapat digambarkan sebagai berikut:

Tabel 1. Desain Penelitian

\begin{tabular}{cccc} 
& Pre Test & Treatment & Post Test \\
\hline (R) & $\mathrm{O}_{1}$ & $\mathrm{X}$ & $\mathrm{O}_{2}$ \\
\hline
\end{tabular}

Keterangan :

R : Randomisasi

$\mathrm{O}_{1} \quad$ : Observasi Awal (Pre test)

$\mathrm{O}_{2} \quad$ : Observasi Akhir Kelompok (Post Test)

$\mathrm{X} \quad$ : Pemberian perlakuan penggunaan video YouTube

\section{Definisi Konseptual}

Pada anak-anak, egosentris merupakan proses perkembangan yang normal dan dapat dimengerti. Pada kenyataannya, mereka hanya berpikir bahwa orang lain melakukan sesuatu seperti apa yang dipersepsiannya. Subjek pada penelitian ini adalah anak usia 4-5 tahun, pemilihan ini dikarenakan pada usia ini anak mampu menguratarakan kalimat atau perlakuan egosentris. Demikian alasan yang menguatkan peneliti dalam menjadikan anak usia 4-5 tahun sebagai subjek penelitian.

Video YouTube Nussa merupakan video yang dapat di tonton oleh anak-anak secara berkelompok, baik kelompok kecil maupun kelompok besar. Video YouTube Nussa sebagai tontonan yang mendidik khususnya untuk anak-

JECIES: Journal of Early Childhood Islamic Education Study 
anak. Mulai dari sikap Nussa dan Rara, ucapan dari Nussa dan Rara, kegiatan, dan nyanyian.

\section{Definisi Operasional}

Secara operasional, Ujaran-egosentris merupakan ungkapan kepada dirinya sendiri untuk dirinya sendiri ketika melakukan suatu aktivitas yang dilakukan oleh anak-anak dengan indikator, (1) berbicara sendiri (2)

Pada Awal Eksperimen $\left(\mathrm{O}_{1}\right)$

Pada Akhir Eksperimen $\left(\mathrm{O}_{2}\right)$

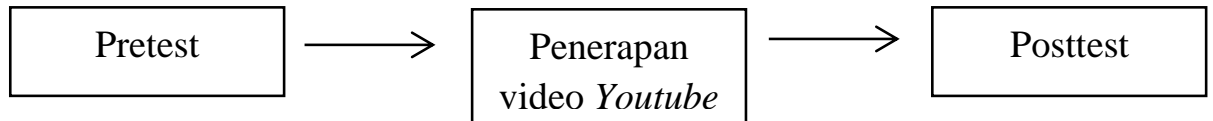

menyelesaikan masalah (3) menyendiri. Egocentric Speech pada anak adalah skor (nilai) yang menunjukkan egocentric speech anak dalam tontonan video YouTube Nusa. Skor-skor diukur dengan skala rentangan 1-4, BM=1, $\mathrm{MM}=2, \mathrm{BSH}=3$, $\mathrm{BSB}=4$, yang dihitung berdasarkan berbicara sendiri, menyelesaikan masalah, menyendiri.

\section{Desain Penelitian}

Metode penelitian yang digunakan adalah penelitian eksperimen gunanya untuk menguji hubungan sebab akibat melalui pengujian hipotesis dengan pendekatan kuantitatif analitik

Desain penelitian ini adalah One Group Pretest-Posttest Design.. Dalam model ini observasi dilakukan sebanyak 2 kali yaitu sebelum eksperimen dan sesudah eksperimen. Observasi yang dilakukan sebelum eksperimen $\left(\mathrm{O}_{1}\right)$ kelompok diberi tes awal atau pretest untuk mengukur kondisi awal, dan observasi sesudah eksperimen $\left(\mathrm{O}_{2}\right),\left(\mathrm{O}_{1} \mathrm{X} \mathrm{O}_{2}\right)$.

\section{Gambar 1. One Group Pretest-Posttest Design} berikut:

Desain penelitian (Kadir, 2015:203) dapat digambarkan sebagai

Tabel 2. Desain Penelitian

\begin{tabular}{cccc}
\hline & Pre Test & Treatment & Post Test \\
\hline$(\mathrm{R})$ & $\mathrm{O}_{1}$ & $\mathrm{X}$ & $\mathrm{O}_{2}$
\end{tabular}

Keterangan :

$\mathrm{R} \quad$ : Randomisasi

$\mathrm{O}_{1} \quad$ : Observasi Awal (Pre test)

JECIES: Journal of Early Childhood Islamic Education Study

Vol. 01, Nomor 01, Januari - Juni 2020 


\section{$\mathrm{O}_{2} \quad$ : Observasi Akhir Kelompok (Post Test) \\ $\mathrm{X} \quad$ : Pemberian perlakuan penggunaan video YouTu}

Berdasarkan tabel, maka dapat dideskripsikan bahwa ada perlakuan yang diberikan kepada kelompok yaitu pre-test pada awal penelitian dan post-test pada akhir penelitian dengan memberikan video YouTube Nussa. Sebelum diberi perlakuan, kelompok eksperimen mengikuti test awal (pre-test) observasi menggunakan lembaran instrument yang diberi tanda checklist dengan video YouTube Nussa untuk mengetahui egocentric speech anak. Ketika perlakuan selesai dilaksanakan kelompok eksperimen diberikan observasi akhir (post test). Hal tersebut kemudian dianalisis untuk dijadikan bahan pengujian hipotesis.

\section{Populasi, Sampel dan Teknik Pengambilan Sampel}

Populasi dalam penelitian ini adalah anak usia 4-5 tahun yang bermain di Ruang Publik Terpadu Ramah Anak Bahari Kelurahan Gandaria Selatan, Kecamatan Cilandak, Kota Administrasi Jakarta Selatan.

Sampel

Teknik pengambilan sampel dalam penelitian ini adalah teknik non probability yakni Incidental sampling, yaitu anggota sampel (responden) yang terpilih adalah seadanya (Darmawan, 2013: 151) Incidental Sampling merupakan teknik penentual sampel berdasarkan kebetulan, yaitu siapa saja yang secara kebetulan/incidental bertemu dengan peneliti dapat digunakan sebagai sampel, bila dipandang orang yang kebetulan ditemui itu cocok sebagai sumber data (dalam Sujarweni: 71)

Alasan pemilihan sampel dengan menggunakan Incidental Sampling adalah karena di tempat penelitian yang peneliti ambil adalah ruangan publik yang ramah anak dengan adanya kegiatan untuk anak-anak, sehingga peneliti menetapkan teknik tersebut dalam penelitian ini.

Pertimbangan didasarkan pada Kriteria yang akan digunakan adalah 12 orang anak usia 4-5 tahun yang bermain di Ruang Publik Terpadu Ramah Anak Bahari, Kelurahan Gandaria Selatan, Kecamatan Cilandak, Kota Jakarta Selatan yang telah berkunjung minimal sebanyak 3 kali. Kriteria ini dipilih karena responden yang telah berkunjung sebanyak 3 kali dianggap telah menjadi pengunjung tetap di Ruang Publik Terpadu Ramah Anak Bahari, Kelurahan Gandaria Selatan, Kecamatan Cilandak, Kota Jakarta Selatan.

\section{Instrumen Penelitian}

Instrument yang diajukan dalam penelitian ini memiliki 10 butir item instrument observasi untuk menilai kemampuan berbahasa anak. Observasi ini dilakukan sebelum (pretest) dan sesudah (protest) perlakuan. Pretest berfungsi sebagai alat untuk mengetahui homogenitas responden. Setiap butirnya berisi 
pernyataan positif yang setiap butir memiliki rentangan nilai : $\mathrm{BM}=1, \mathrm{BSH}=$ $3, \mathrm{MM}=2, \mathrm{BSB}=4$.

Tabel 3. Tabel Rubrik Penilaian

\begin{tabular}{|c|c|c|}
\hline SKOR & KODE & KETERANGAN \\
\hline 1 & BM & $\begin{array}{l}\text { Jika anak tidak mampu menjawab semua } \\
\text { pertanyaan }\end{array}$ \\
\hline 2 & MM & $\begin{array}{l}\text { Jika anak hanya mampu menjawab } 2 \\
\text { pertanyaan }\end{array}$ \\
\hline 3 & $\mathrm{BSH}$ & $\begin{array}{l}\text { Jika anak telah mampu menjawab } 3 \\
\text { pertanyaan tanpa bantuan }\end{array}$ \\
\hline 4 & BSB & $\begin{array}{l}\text { Jika anak telah mampu menjawab } 4 \\
\text { pertanyaan tanpa bantuan. }\end{array}$ \\
\hline
\end{tabular}

\section{Teknik Analisis Data}

Teknik analisis data penelitian ini dianalisa dengan menggunakan analisis sebagai berikut: Deskripsi Data (Statistika Deskripsif), Uji Persyaratan Analisis (Uji Normalitas).Uji normalitas dengan teknik Liliefors adalah dengan menentukan taraf signifikansi $(\alpha)$ misalkan pada $\alpha=5 \%$ atau 0,05 dengan hipotesis yang akan diuji: $\mathrm{H}_{0}$ : data berdistribusi normal, $\mathrm{H}_{1}$ : data tidak berdistribusi normal. Dengan kriteria pengujian: Jika Lo $=\mathrm{L}_{\text {hitung }}<\mathrm{L}_{\text {tabel }}$ maka Ho diterima. Jika Lo $=\mathrm{L}_{\text {hitung }}>\mathrm{L}_{\text {tabel }}$ maka Ho ditolak. Penelitian menggunakan uji normalitas dengan rumus Lilliefors sebagai berikut :

$$
\mathrm{Lo}=[\mathrm{F}(\mathrm{Zi})-\mathrm{S}(\mathrm{Zi})]
$$

Keterangan :

L0 : Normalitas

$\mathrm{F}(\mathrm{Zi}) \quad$ : Nilai $\mathrm{Z}$ ( peluang pada kurva normal)

$\mathrm{S}(\mathrm{Zi}) \quad$ : Proporsi data Z terhadap keseluruhan

Uji Homogenitas

Menurut Kadir (dalam Ananda:164), uji homogenitas adalah distribusi data menggunakan uji Bartlet adalah untuk mengetahui apakah data tersebut homogeny atau tidak homogeny pada taraf $\alpha=0,05$. Uji homogenitas swebagai berikut:

$$
\begin{aligned}
& X^{2}=(\operatorname{In} 10)\left(\mathrm{B}-\sum\left(\mathrm{n}_{\mathrm{i}}-1\right) \log \mathrm{s}_{\mathrm{i}}{ }^{2}\right) \\
& \mathrm{S}^{2}=\frac{\sum(\mathrm{ni}-1) \mathrm{si}^{2}}{\sum 9 \mathrm{NI}-10}
\end{aligned}
$$




\section{Uji Hipotesis}

Pengujian ini dilakukan pada taraf signifikan $\alpha=0.05$. Uji-t digunakan untuk menguji hipotesis masing-masing kelompok baik yang belum mendapat perlakuan maupun yang sudah mendapatkan perlakuan, sehingga pada rumus uji-t memasukkan standar error. Rumus yang digunakan adalah :

$$
\mathrm{t}_{0}=\frac{|\overline{\mathrm{Y}} 1-\overline{\mathrm{Y}} 2|}{\sqrt{\mathrm{S \overline {y }}_{1}{ }^{2}+\mathrm{Sy}_{2}{ }^{2}-2 \mathrm{ry}_{1} \mathrm{y}_{2} \mathrm{~S} \overline{\mathrm{y}}_{1} \mathrm{~S} \overline{\mathrm{y}}_{2}}}
$$

Keterangan :

S : Varians

$\overline{\mathrm{Y}} 1 \quad$ : rata-rata kelompok ke 1

$\overline{\mathrm{Y}} 2$ : rata-rata kelompok ke 2

r : $\quad$ korelasi

\section{Hipotesis Statistika}

Hipotesis penelitian yang diajukan peneliti adalah pengaruh video YouTube Nussa terhadap egocentric speech anak usia 4-5 tahun.

Hipotesis nol $\left(\mathrm{H}_{0}\right)$ ditolak atau Hipotesis alternatif $\left(\mathrm{H}_{1}\right)$ diterima, jika $t_{\text {hitung }}>\mathrm{t}_{\text {tabel, }}$, berarti egocentric speech yang menggunakan media sosial YouTube lebih tinggi dari kemampuan berbicara anak tanpa video YouTube "NUSSA". Dengan demikian menunjukkan, terdapat pengaruh penggunaan video YouTube "NUSSA" terhadap kemampuan berbicara anak usia 4-5 tahun di Ruang Publik Terpadu Ramah Anak Bahari Kelurahan Gandaria Selatan Kecamatan Cilandak Kota Jakarta Selatan.

\section{KAJIAN TEORITIS}

Egosentris (Karen, 2007 :6) didefinisikan sebagai: 1) memiliki atau menganggap diri sebagai pusat dari segala sesuatu, terutama sebagaimana diterapkan pada dunia yang dikenal. 2) memiliki sedikit tidak mempedulikan untuk kepentingan, kepercayaan, atau sikap selain dari milik sendiri; pusat perhatian. Gagasan tentang pidato egosentris sangat penting dalam teori pengembangan bahasa anak selama tahun 1920-an dan 1930-an. Sejak itu telah diterima sebagai tahap dalam perkembangan komunikatif dan kognitif anak.

Piaget mengungkapkan bahwa egosentris adalah bahwa anak-anak di bawah 7 atau 8 tahun sebagian besar egosentris, atau tidak bisa mengambil sudut pandang orang lain. Ini diilustrasikan tiga studi khususnya: orang-orang dari pidato egosentris, keterampilan komunikasi, dan istilah relasional. Dalam pidatonya egosentris adalah mencoba untuk mendapatkan ukuran obyektif dari egosentrisme pemikiran. Pidato egosentris terjadi baik ketika anak itu sendirian atau ketika dia tidak berusaha untuk menempatkan dirinya pada titik 
pandangan pendengarnya. Sementara Pidato di sosialisasikan terjadi ketika anak mengadopsi sudut pandang pendengarnya. Piaget menemukan bahwa untuk kelompok kecilnya subjek koefisien dari egosentris (proporsi pidato egosentris terhadap total pidato) sekitar 40-50\% antara 3 dan 6 tahun, dan menurun cepat sekitar 7 atau 8 tahun.

Piaget menambahkan bahwa anak berkembang dari tahap perkembangan autistik ke tahap sosialisasi. Selama pergeseran perkembangan ini ujaran-egosentris muncul sebagai bentuk transisi antara pidato autistik dan diarahkan sosial. Piaget tidak menyangkal bahwa bahkan orang dewasa berbicara kepada diri mereka sendir.

Vygotsky (Huges,1975:3) juga mengatakan bahwa "independen dari ucapan sosial; namun kemandirian itu tidak lengkap karena tidak dirasakan sebagai ucapan batin dan tidak dibedakan oleh anak dari ucapan untuk orang lain."

Menurut Wardswoth dalam JoungChul (Jeong Chu Heo:753), egosentrisme dapat mengambil bentuk yang berbeda di berbagai tingkat perkembangan, tetapi selalu ditandai dengan kurangnya diferensiasi. Oleh karena itu, anak-anak kecil mempertimbangkan perbedaan antara pengetahuan dan informasi rekan mereka sendiri dalam perkembangan kognitif awal mereka

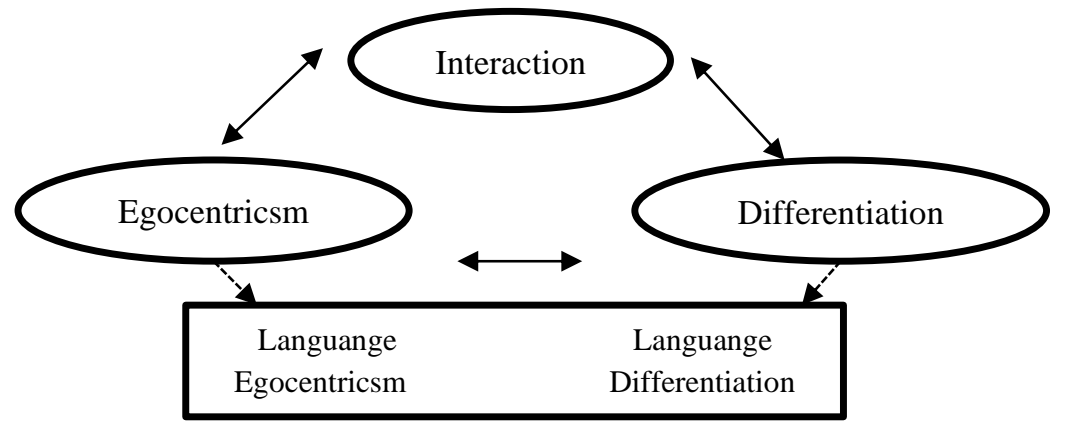

Gambar 1. Hubungan antara Egosentrisme dan Diferensiasi

Wardsworth berpendapat bahwa anak sensorimotor awalnya egosentris dalam hal dia tidak memiliki diferensiasi antara diri sebagai objek dan objek lainnya. telah menunjukkan bahwa anak praoperasi pada awalnya tidak dapat membedakan antara pikiran orang lain dan pikirannya sendiri. pada gambar diatas, diferensiasi egosentrik, dan interaksi sangat terkait, dan pemikiran egosentris anak-anak pada tahap praoperasi akan berkurang dengan penambahan interaksi dan kognitif, sementara pemikiran diferensial meningkat pada tahap konkret dan formal anak.

Doran dan Cowan juga mengemukakan bahwa ukuran interaksi rekan tidak berkorelasi dengan salah satu dari beberapa ukuran egosentrisme 
(misalnya, egosentrisme spasial, egosentrisme komunikasi, atau keterampilan mengambil peran) dan menyimpulkan bahwa egosentrisme bukan variabel kesatuan, sedangkan Piaget mengemukakan bahwa salah satu faktor lingkungan terpenting yang menyebabkan berkurangnya egosentrisme terkait dengan interaksi seorang anak dengan teman-temannya. Selain itu, Deutsch menemukan hubungan antara interaksi teman sebaya dan egosentrisme komunikasi pada anak-anak prasekolah.

Pada dasarnya, Egosentrisme dapat dipandang sebagai mekanisme pembelajaran internal, dan memiliki peran yang jauh lebih sentral untuk dimainkan dalam pembelajaran bahasa dengan berbagai interaksi. selain itu, seorang anak dengan tingkat pemikiran logis yang tinggi tentang diferensiasi tidak berarti bahwa ia akan menggunakan proporsi yang rendah terhadap tingkat diferensiasi, dan tidak memiliki tahap lanjut seperti perkembangan kognitif Piaget. Dengan kata lain, egosentrisme atau diferensiasi dapat dipandang sebagai kecenderungan belajar yang dominan (atau belajar mekanisme) bagi siswa dalam pembelajaran bahasa dan penguasaan bahasa kedua.

Anak-anak dan perempuan bisa mendapatkan tingkat yang lebih tinggi dari mekanisme pembelajaran dominan egosentrisme bahasa jika dibandingkan dengan orang dewasa dan laki-laki yang memiliki tingkat yang lebih tinggi dalam pembelajaran pembelajaran bahasa (Jeong Chung Heo). Oleh karena itu, egosentrisme bahasa dapat disebut sebagai kecenderungan pembelajaran bawaan bawaan dan mekanisme milik egosentrisme yang membantu anak-anak dalam pembelajaran mereka.

Piaget mengamati bahwa jika anak-anak perempuan yang berusia 5 tahunan bermain kotak pasit, contohnya, maka masing-masing dari mereka berbicara dengan antusias tentang topik-topik yang sebenrarnya tidak bisa dibayangkan anak lain. Piaget menyebut ujaran ini 'egosentrik' karena dia melihat ujaran tersebut merefleksikan egosentrisme umum anak.anak. mereka tidak menyesuaikan ujarannya sesuai perspektif pendengar karena secara egosentris dia berasumsi perspektif pendengar sama dengan persepsinya sendiri. Paget memperkirakan $45 \%$ dari anak-anak usa 4 sampai 7 tahun menggunakan ujaran-egosentris ini.

Vygotsky setuju jika ujaran-egosentris sangat dominan di kelompok usia ini, namun dia tidak setuju dengan interpretasi Piaget. Di mata piaget, ujaran-egosentris tidak berguna selain hanya merefleksikan kelamahan di dalam pikiran anak.

Vygotsky (wiliam, 2007:352) juga menyatakan, ujaran anak yang terarah pada diri sendiri sangat membingungkan karena belum terbedakan dari ujaransosial. Sang anak berusaha mengguanakn ujaran untuk mengarahkan aktivitasnya sendiri namun masih memakainya seperti komunikasi sosial. 
Masih butuh waktu lebh banyak lagi ujaran yang terarah pada diri sendiri ini untuk jadi 'terbedakan' dan mengambil karakternya sendiri. Perubahan itu pun terjadi hanya secara bertahap, menjadi lebih diam, ringkas, dan ucapan-dalamhati.

Di samping itu, Miller (Izzaty: 493) menyatakan bahwa sejumlah faktor perkembangan sebagai ciri khas anak prasekolah yang dapat mempengaruhi perilaku atau respon yang diberikannya terhadap sesuatu,diantaranya sifat egosentris. Istilah egosentris merupakan proses perkembangan yang normal dan dapat dimengerti. Kenyataannya, mereka hanya berpikir bahwa orang lain melakukan sesuatu seperti apa yang dipersepsiannya. Sebagai akibatnya, pada anak prasekolah sering terlihat sifat kurang sabar dan menginginkan apa yang diinginkannya segera diraih, dengan berbagi cara yang menarik perhatian lingkungan sekitarnya.

Vygotsky juga berpandangan bahwa ujaran egosentris tidak hilang tetapi mengalami transformasi genetik dan berubah menjadi apa yang dia namakan inner speech, Hubungan antara inner speech dengan external speech mau-tidak-mau harus memanfaatkan bunyi karena ujaran hanya dapat terwujud dengan bunyi fonetik. Inner speech masih tetap suatu ujaran, yakni, pikiran yang berkaitan dengan kata. External speech pikiran itu terwujudkan dalam kata sedangkan pada inner speech kata-kata itu lenyap pada saat pikiran itu terbentuk. Pada saat anak tumbuh, berpikir yang terujarkan menjadi makin kecil dan setelah dewasa berpikir tidak lagi dilakukan dengan memakai kata yang terujarkan. Jarak yang makin jauh antara inner speech dengan bunyi fonetik yang dipakai untuk mewakilinya mempercepat proses berpikir.

Egosentrisme (Hurloc, 1978: 262) berarti perhatian kepada diri sendiri melebihi perhatian kepada orang lain. Anak yang egosentrik terikat pada dirinya, dalam arti bahwa perhatian mereka terutama berpusat kepada diri mereka sendiri. Meraka lebih banyak berpikir dan berbicara tentang diri sendiri daripada tentan orang lain dan tindakan mereka terutama bertujuan menguntungkan diri.

Berdasarkan beberapa pendapat di atas dapat disimpulkan bahwa egocentric speech merupakan ungkapan kepada dirinya sendiri, untuk dirinya sendiri ketiika melakukan suatu aktivitas yang dilakukan oleh anak-anak.

\section{YouTube}

Menurut Brad \& Debra (Kiffyah: 201) mendefinisikan YouTube adalah:

"a community where people are entertained, informed, educated, and inspied through the sharing of video".

Sementara Baskoro (dalam Aria Indhi) mengemukakan bahwa YouTube merupakan situs video yang menyediakan berbagai informasi berupa 'gambar bergerak' dan bisa diandalkan.. 
YouTube mulai dikembangkan di San Mateo, California dengan domain bernama www.youtube.com. Situs tersebut kemudian mulai aktif dan memulai beta test di tanggal 14 Februari 2005 dan kemudian terus dikembangkan di bulan-bulan berikutnya hingga bulan Oktober 2006.

Video pertama kali (dalam Kompas) yang diunggah ke YouTube berjudul Me at the Zoo, Video tersebut milik salah satu pendiri YouTube, Jawed Karim di San Diego Zoo pada hari Sabtu, 23 April 2005 jam 20.27 waktu San Francisco, Amerika Serikat. Sampai saat ini YouTube menjadi situs online video provider paling dominan yang didatangi di Dunia. Dengan menguasai lebih dari 43 persen pasar dunia. Dengan 20 jam video yang diupload ke YouTube setiap menitnya dan dilihat sampai lebih dari 6 milyar pageview setiap harinya.

Berdasarkan beberapa pendapat di atas dapat disimpulkan bahwa YouTube merupakan situs video online yang merupakan sarana informasi, pendidikan,dan pengetahuan, untuk mendapatkan pengetahuan maupun informasi.

\section{Kerangka Berpikir}

Dalam penelitian ini akan dilaksanakan pretest pada satu kelompok sampel yaitu kelas eksperimen untuk mengetahui kemampuan awal anak-anak, kemudian akan diberi perlakuan dengan memberikan video YouTube "NUSSA". Setelah itu diadakan posttest untuk mengetahui egocentric speech anak guna mengukur pengaruh video YouTube NUSSA dapat diilustrasikan dalam bagan sebagai berikut.

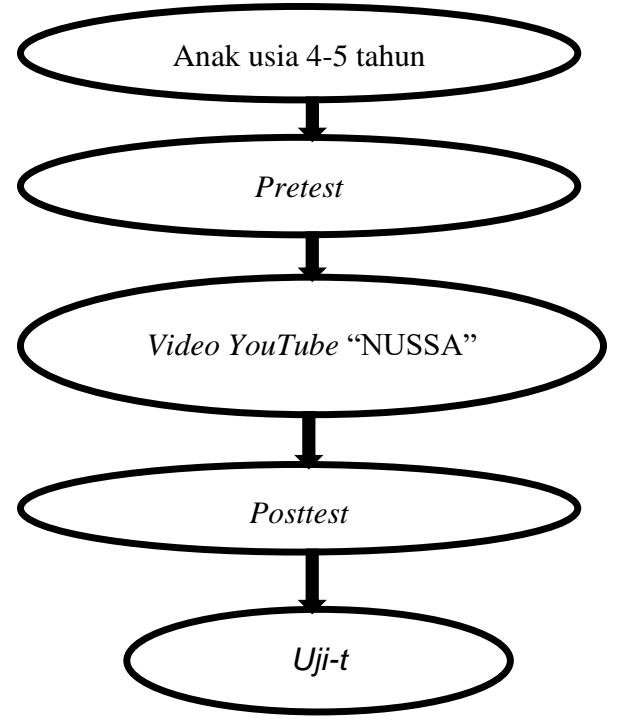

Gambar 2. Kerangka Berpikir

JECIES: Journal of Early Childhood Islamic Education Study

Vol. 01, Nomor 01, Januari - Juni 2020 


\section{HASIL PENELITIAN}

Penelitian ini terdiri dari sebelum diberi perlakuan (pre-test) dan sesudah diberi perlakuan (post-test) tentang video YouTube Nussa yang diberikan dengan menggunakan metode. Deskripsi data akan diuraikan dalam bentuk skor egocentric speech sebelum diberi perlakuan (pre-test) dan sesudah diberikan perlakuan (post-test). Perlakuan dalam penelitian ini adalah pemberian Video YouTube Nussa. Apaun deskripsi tersebut adalah nilai minimum, nilai maksimum, rata-rata (mean), standar deviasi, dan tabel distribusi frekuensi.

Untuk lebih jelasnya dapat disajikan dalam bentuk tabel distribusi frekuensi dan histogram di bawah ini:

Tabel 4. Deskripsi Data Egocentric Speech

\begin{tabular}{lclc}
\hline \multicolumn{4}{c}{ Egocentric Speech } \\
\hline & $\begin{array}{c}\text { Pre-test } \\
\left(Y_{1}\right)\end{array}$ & $\begin{array}{c}\text { Post-test } \\
\left(Y_{2}\right)\end{array}$ \\
\hline$n$ & $=12$ & $n$ & $=12$ \\
$\sum Y_{1}$ & $=288$ & $\sum Y_{2}$ & $=445$ \\
$\sum Y^{2}$ & $=7058$ & $\sum Y^{2}$ & $=16573$ \\
$\sum y^{2}$ & $=146$ & $\sum y^{2}$ & $=70,91$ \\
$\bar{x}$ & $=24$ & $\bar{x}$ & $=37,08$ \\
\hline
\end{tabular}

\section{Egocentric Speech Sebelum diberi Perlakuan $\left(\mathrm{Y}_{1}\right)$}

Berdasarkan pada data yang telah dikumpulkan dari responden sebanyak 12 orang anak, diperoleh data kelompok anak yang sebelum diberi perlakuan pemutaran video YouTube dengan perolehan skor tertingi 30; skor terendah 20; rata-rata (mean) 24; nilai median $\left(M_{c}\right)$ 22,5; nilai modus $\left(M_{\circ}\right) 22$, dan simpangan baku 3,89. Untuk lebih jelasnysa dapat dilihat pada deskripsi data dituangkan dalam bentuk tabel distribusi frekuensi sebagai berikut:

Tabel 5. Distribusi Frekuensi Skor Egocentric Speech Anak Sebelum diberi Perlakuan $\left(\mathrm{Y}_{1}\right)$

\begin{tabular}{cccc} 
Kelas Interval & $\begin{array}{c}\text { Frekuensi } \\
\text { Absolut }\end{array}$ & $\begin{array}{c}\text { Frekuensi } \\
\text { Komulatif }\end{array}$ & $\begin{array}{c}\text { Frekuensi } \\
\text { Relatif }\end{array}$ \\
\hline $20-21$ & 3 & 3 & $25 \%$ \\
\hline $22-23$ & 4 & 7 & $33,33 \%$ \\
\hline $24-25$ & 1 & 8 & $8,33 \%$ \\
\hline $26-27$ & 0 & 8 & $0 \%$ \\
\hline
\end{tabular}




\begin{tabular}{cccc}
\hline $28-29$ & 2 & 10 & $16,67 \%$ \\
\hline $30-31$ & 2 & 12 & $16,67 \%$ \\
\hline Jumlah & $\mathbf{1 2}$ & & $\mathbf{1 0 0 \%}$ \\
\hline
\end{tabular}

Distribusi frekuensi skor egocentric speech anak sebelum diberi pelakuan yang diberi video YouTube Nussa seperti pada gambar berikut:

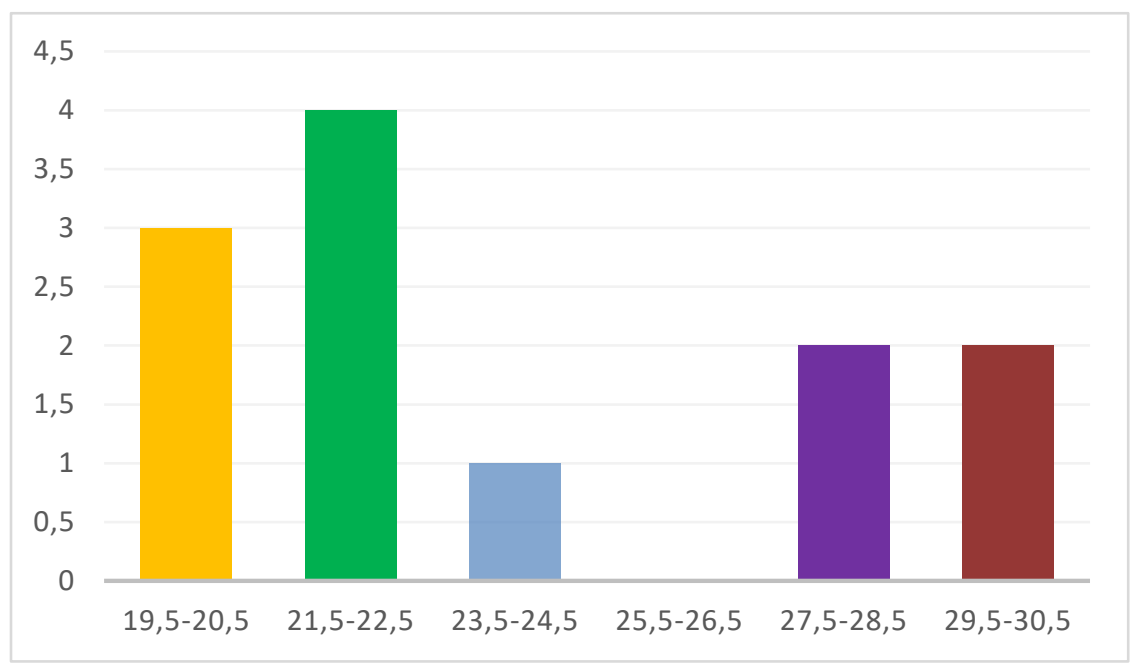

Gambar 1. Histogram Distibusi Frekuensi Kelompok $Y_{1}$

\section{Hasil Egocentric Speech Anak sesudah diberi Perlakuan $\left(\mathrm{Y}_{2}\right)$}

Berdasarkan pada data yang telah dikumpulkan dari responden sebanyak 12 orang anak, diperoleh data kelompok anak setelah diberi perlakuan video YouTube Nussa dengan perolehan skor tertingi 40; skor terendah 32; rata-rata (mean) 37,08; median $\left(\mathrm{M}_{\mathrm{e}}\right)$ 39,5; nilai modus $\left(\mathrm{M}_{\circ}\right)$ 36,5; dan simpangan baku 2,539. Untuk lebih jelasnya dapat dilihat pada deskripsi data dituangkan dalam bentuk tabel distribusi frekuensi sebagai berikut:

Tabel 6. Distribusi Frekuensi Skor Egocentric Speech Anak Sesudah diberi

Perlakuan $\left(\mathrm{Y}_{2}\right)$

\begin{tabular}{cccc}
\hline Kelas Interval & $\begin{array}{c}\text { Frekuensi } \\
\text { Absolut }\end{array}$ & $\begin{array}{c}\text { Frekuensi } \\
\text { Komulatif }\end{array}$ & $\begin{array}{c}\text { Frekuensi } \\
\text { Relatif }\end{array}$ \\
\hline $32-33$ & 1 & 2 & $8,33 \%$ \\
\hline $34-35$ & 2 & 2 & $16,67 \%$ \\
\hline $36-37$ & 4 & 2 & $33,33 \%$ \\
\hline $38-39$ & 2 & 8 & $17 \%$ \\
\hline
\end{tabular}




\begin{tabular}{cccc}
\hline $40-41$ & 3 & 12 & $25,00 \%$ \\
\hline Jumlah & $\mathbf{1 2}$ & & $\mathbf{1 0 0 , 0 0 \%}$ \\
\hline
\end{tabular}

Distribusi frekuensi skor egocentric speech anak sesudah diberi pelakuan yang diberi video YouTube Nussa selanjutnya dapat disajikan dalam histrogram seperti pada gambar berikut

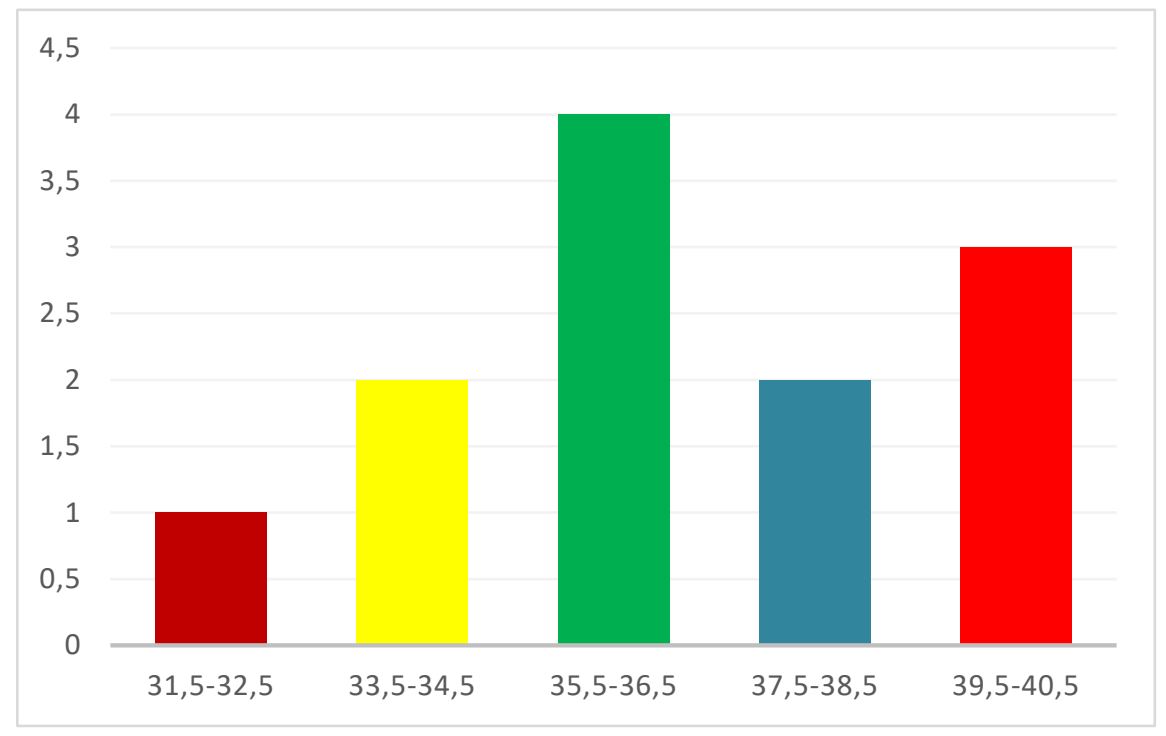

Gambar 2. Histogram Distibusi Frekuensi Kelompok $\mathrm{Y}_{2}$

\section{Pengujian Persyaratan Analisis Data}

\section{Uji Normalitas}

Hasil perhitungan uji normalitas dengan uji Lilliefors secara keseluruhan dapat dilihat pada tabel berikut:

Tabel 7. Rekapitulasi Hasil Uji Normalitas Sampel dengan Uji Lilliefors pada Taraf $\alpha=0,05$

\begin{tabular}{ccccc}
\hline Kelompok & $\begin{array}{c}\text { Jumlah } \\
\text { Sampel }\end{array}$ & Lhitung $\left(\mathbf{L}_{\mathbf{0}}\right)$ & Ltabel $\left(\mathbf{L}_{\mathbf{t}}: \boldsymbol{\alpha = 0 , 0 5 )}\right.$ & Kesimpulan \\
\hline $\mathbf{Y}_{\mathbf{1}}$ & 12 & 0,197 & 0,242 & Normal \\
\hline $\mathbf{Y}_{\mathbf{2}}$ & 12 & 0,221 & 0,242 & Normal \\
\hline
\end{tabular}


Dari hasil analisis normalitas data pada tabel diatas, menunjukkan bahwa harga $p$-value untuk semua kelompok adalah $>0,05$, sehingga $\mathrm{H}_{0}$ diterima atau kedua data kelompok tersebut berdistribusi normal.

\section{Uji Homogenitas}

Berdasarkan hasil perhitungan $t_{\text {hitung }}=2,12$. Berdasarkan daftar tabel $t_{\text {tabel }(\alpha=0,05 ; 10)}=1,812$. Dengan demikian diperoleh $t_{\text {hitung }}>t_{\text {tabel, }}, H_{0}$ diterima, ini berarti skor egocentric speech dari kedua kelompok tersebut berasal dari populasi yang homogen.

\section{Pengujian Hipotesis}

Kriteria pengujian yang digunakan yaitu terima $\mathrm{H}_{1}$ dan tolak $\mathrm{H}_{0}$ jika $t_{\text {hitung }}>t_{\text {tabel. }}$. Untuk leih jelasnya perhitung hipotesis dilihat pada tabel di bawah

Tabel 8. Hasil Uji Hipotesis

\begin{tabular}{llccc}
$\begin{array}{c}\text { Sumber } \\
\text { varians }\end{array}$ & $\begin{array}{c}\text { Selisih } \\
\mathbf{Y}_{1}-\mathbf{Y}_{2}\end{array}$ & $\mathbf{t}_{\text {hitung }}$ & $\mathbf{t}_{\text {tab (0,05) }}$ & Keterangan \\
\hline Kelompok & $\mathbf{1 3 , 0 5}$ & $\mathbf{8 , 5 8}$ & $\mathbf{1 , 8 1}$ & Tolak $\mathbf{H}_{\mathbf{0}}$ \\
\hline \multicolumn{4}{l}{$\begin{array}{l}\text { Karena } \mathrm{H}_{\mathrm{o}} \text { ditolak maka } \mathrm{H}_{1} \text { diterima, terdapat perbedaan skor egocentric } \\
\text { speech anak sebelum dan sesudah diberi perlakuan video YouTube Nussa }\end{array}$} \\
\hline
\end{tabular}

Dengan demikian dapat disimpulkan bahwa egocentric speech pada kelompok anak yang telah diberi video YouTube Nussa memperoleh skor lebih besar dari egocentric speech yang belum diberi video YouTube Nussa.

\section{Interpretasi Hasil Penelitian}

Dari uji homogenitas menunjukkan bahwa video YouTube dapat memberikan pengaruh terhadap egocentric speech anak. Berdasarkan perbedaan ini dapat disimpulkan bahwa $\mathrm{t}_{\text {hitung }}=8,58 \mathrm{dan}>\mathrm{t}_{\text {tabel }}(0,05,10)$ terdapat perubahan skor, maka terdapat pengaruh video YouTube Nussa terhadap egocentric speech anak.

\section{KESIMPULAN}

Berdasarkan hasil penelitian dan pembahasan diperoleh kesimpulan bahwa hasil nilai rata-rata egocentric speech kelompok anak yang diberikan (posttest) pada video YouTube Nussa lebih tinggi dibandingkan nilai egocentric speech pada kelompok anak yang diberi perlakuan (pre-test) video YouTube Nussa. Hal ini berdasarkan perhitungan bahwa diperoleh nilai $t_{\text {hitung }}(8,58)>t_{\text {tabel }}(1,81)$ pada taraf signifikansi $\alpha=0,05$, maka $\mathrm{H}_{1}$ diterima dan $\mathrm{H}_{0}$ ditolak.

JECIES: Journal of Early Childhood Islamic Education Study

Vol. 01, Nomor 01, Januari - Juni 2020 


\section{REFERENSI}

Arikunto, Prosedur Penelitian Suatu Pendekatan Praktik. Jakarta: Rineka Cipta, 2002.

Crain Wilian, Teori Perkembangan Konsep dan Aplikasi, Yogyakarta: Pustaka Pelajar, 2007.

Deni, Darnawan. Metode Penelitian Kuantitatif. Bandung: PT Remaja Rosdakarya, 2013.

Faiqah, Fatty, dkk. YouTUbe Sebagai Sarana Komunikasi Bagi Komunitas Makassarvidgram. Jurnal Komunikasi KAREBA, Vol. 5 No. 2. Makassar: Universitas Hasanuddin, 2016.

Hendru. 2014. "Negara dengan Penduduk Terbanyak di Dunia, RI masuk 4 Besar", Detik Finance https:/ finance.detik.com/berita-ekonomibisnis/d-2517461/negara-dengan-penduduk-terbanyak-di-dunia-rimasuk-4-besar, diakses pada 07 November 2018

Hidayat, Wicak. 2014. "Penggunaan Internet Indonesia Nomor Enam Dunia", Kominfo https://kominfo.go.id/content/detail/4286/pengguna-internetindonesia-nomor-enam-dunia/0/sorotan_media, diakses pada 07 November 2018

Hurlock Elizabeth B. Perkembangan Anak. PT Perlora Aksara Pratama.

Indhi Aria. "Fenomena YouTube Sebagai Media Penyiaran di Zaman Modern". https://www.kompasiana.com/ariaindhi/597000eded967e0aed056e1 2/fenomena-youtube-sebagai-media-penyiaran-di-zamanmodern?page $=$ all diakses 14 Februari 2019

JeongCHul Heo, et.al. Piaget's Egocentrism and Languange Learning: Language Egocentrism (LE) and Language Differentioation (LD), Findland: Journal Of Languange Teaching and Research, Findland

Kadir, Statistika Terapan. Raja Grafindo Persada, 2015 
Karen Junefet, Rethinking Egocentric Speech, New York: Nova Science Publishers, Inc. 2007.

Kiftiyah, Iva Nur, et.al. (Peran Media Youtube Sebagai Sarana Optimalisasi Perkembangan Kgntif pada Anak Usia Dini, Kediri: STAIN Kediri.

Martin Huges, Egocentrism In Preschool Children, United Kingdom: The University Of Edinburgh, 1975.

Setiawan, Sakina Rakhma Diah. 2018. "Hampir 90 Persen Penggunaan Internet di Indonesia untuk "Chatting"', https://ekonomi.kompas.com/read/2018/02/19/171500926/hampi r-90-persen-penggunaan-internet-di-indonesia-untuk-chatting-, diakses pada 07 November 2018

STKIP Kusuma Negara Jakarta. Buku Pedoman Penulisan dan Bimbingan Skripsi. Jakarta: STKIP Kusuma Negara Jakarta, 2015.

Sudjana Anas, Pengantar Statistik Pendidikan. Jakarta: Rajawali Pers, 2011.

Surjaweni, W. Wiratna. Metedologi Penelitian. Yogyakarta: PT Pustaka Baru, 2014. 